\title{
Reversible Nervous Abnormalities in Juvenile Diabetics with Recently Diagnosed Diabetes
}

\author{
A.B. Terkitdosen and N.J. Christensen
}

Second Clinic of Internal Medicine, Kommunehospitalet, Århus University School of Medicine, Århus, Denmark

Received: July 7, 1970, accepted: January 6, 1971

Summary. It has been well documented that diabetic patients retain vibratory perception during a longer period of ischaemia than non-diabetics. This neurological abnormality is present at the time of the clinical appearance of diabetes and can be normalized by treatment with insulin. - In the present study the vibratory perception threshold was studied during ischaemia in six diabeties before and after treatment with insulin and in six nondiabetics. Threshold values were measured in the big toe, and ischaemia induced by inflating a pressure cuff placed. either above the knee or at the level of the ankle. - The results obtained show that a normal function of only a part of the length of the nerve fibre is required to obtain a normal ischaemic response throughout the length of the nerve, presumably because this part will stop conduction as if the whole nerve fibre were fully repaired. - Furthermore, it is demonstrated that during treatment with insulin, normalization occurs at a greater rate in the prox. imal parts of the nerves compared with the more distal parts. - The ischaemic abnormalities are believed to be due to a defective myelin sheath.

Anomalies nerveuses réversibles chez des diabétiques jeunes ayant un diabète récemment diagnostiqué

Résumé. Il est bien connu que les diabétiques conservent la perception vibratoire pendant une période d'ischémie plus prolongée que les non-diabétiques. Cette anomalie neurologique est présente au moment de l'apparition clinique du diabète et peut être normalisée par le traitement à l'insuline. - Dans le présent travail, le seuil de perception vibratoire a été étudié au cours de l'ischémie chez six diabétiques avant et après traitement par l'insuline et chez six non-diabétiques. Les valeurs de seuil ont été mesurées dans le gros orteil, ot l'ischémie a été induite en gonflant un brassard de pression placé soit au-dessus du genoux, soit au niveau de la cheville. - Les résultats obtenus montrent qu'un fonctionnement normal d'une partie seulement de la longueur de la fibre nerveuse suffit pour obtenir une réponse ischémique normale tout au long du nerf, probablement parce que cette partie arrêtera la conduction comme si la fibre nerveuse toute entière était complètement réparée. - En outre, il est démontré qu'au cours du traitement par l'insuline, la normalisation survient plus fréquemment dans les parties proximales des nerfs par comparaison avec les parties plus distales. - On pense que les anomalies ischémiques sont dues à une gaine de myéline défectueuse.

Reversible neurologische Anomalien bei jugendlichen Diabetikern mit frisch entdecktem Diabetes.

Zusammenfassung. Es ist hinreichend belegt, daß das Vibrationsempfinden bei Diabetikern. während einer längeren Ischämie-Periode als bei Nichtdiabetikern erhalten bleibt. Diese neurologische Anomalie ist bereits bei der klinischen Manifestation des Diabetes nachweisbar und läßt sich durch Insulinbehandlung normalisieren. - In der vorliegenden Untersuchung wurde der Schwellenwert für das Vibrationsempfinden bei 6 Diabetikern vor und nach Insulinbehandlung und bei 6 Nichtdiabetikern untersucht. Die Schwellenwerte wurden am Großzeh gemessen und die Ischämie durch Anlegen einer Staubinde oberhalb des Knies oder in der Knöchelgegend ausgelöst. - Die erzielten Resultate zeigen, daß, um eine normale Ischämie-Reaktion für die Gesamtlage des Nerven zu erhalten, nur ein Teil der Länge dor Nervenfaser normal funktionieren muß, wahrscheinlich weil dieser Teil aufhören wird zu leiten, als ob die ganze Nervenfaser völlig repariert sei. - Weiter konnte gezeigt werden, daß während der Insulinbehandlung die Normalisierung in den proximalen Vervenabschnitten schneller als in den distalen Bezirken eintritt. - Die unter Ischämie nachweisbaren Anomalien werden auf eine defekte Myelin-Scheide bezogen.

Key-words: Juvenile diabetics, nervous abnormalities, vibratory perception threshold, ischaemia, metabolic, insulin treatment.
Diabetic patients retain vibratory perception during ischaemia longer than non-diabetics. This abnormality is found even in patients with newly diagnosed diabetes, and it can be normalized after several days of intensive treatment with insulin $[2,5$, $11,12]$.

Further studies in diabetics have demonstrated that the retained ability to conduct nerve impulses during ischaemia also applies to other sensory modalities as well as to conduction in efferent nerves $[1,5,9]$.

A recent study demonstrated that the prolonged preservation of sensory transmission during ischaemia is not confined to diabetics, but also occurs in a large proportion of uraemic patients [2].
It has been proposed elsewhere [2] that the pathophysiological mechanism responsible for this phenomenon in diabetics as well as in uraemic patients, is a widespread although not necessarily extensive demyelination of the nerves.

According to this theory, normalization of the vibratory perception threshold pattern during intensive insulin treatment would be achieved if a small part of the nerve fibre had become entirely remyelinated, because this small, remyelinated part of the nerve would prevent nerve conduction at the same point in time as in a fully myelinated nerve.

The purpose of the present study was to test this possibility. 


\section{Methods and Procedure}

The vibratory perception threshold, expressed in volts, was measured in the big toe by a standardized technique [13] with a biothesiometer (Bio-Medical Instrument Co., Chagrin Falls, Ohio); 50 volts on the biothesiometer corresponding to maximal amplitude of oscillations. Ischaemia was produced by inflating a pressure cuff placed above the knee to a pressure $80 \mathrm{~mm}$ $\mathrm{Hg}$ greater than systolic pressure. The vibratory perception threshold was measured before arterial occlusion and thereafter at $5 \mathrm{~min}$ intervals for $30 \mathrm{~min}$. In the following this is called the classical technique.

In addition to measurements performed using the classical technique, the vibratory perception threshold in the big toe was also measured with the arterial cuff placed at the level of the ankle. This procedure will be called the modified technique.

The experimental procedure was as follows. Values of the vibratory perception threshold were measured during ischaemia produced by an arterial cuff placed above the right knee and another cuff placed around the left ankle. The following day the same experiment was performed employing arterial cuffs above the left knee and around the right ankle. These measurements were performed once in the control subjects. In the diabetics the same measurements were performed once before treatment with insulin.

During intensive insulin treatment threshold values were measured every second day using an arterial cuff placed above the knee. When a normal response was elicitated the same measurements were performed as before treatment with insulin.

In two patients the procedure was slightly different, measurements being performed on the right leg only. When a normal response had been achieved employing the classical technique during intensive insulin therapy, threshold values during ischaemia were measured with the modified technique the following day.

Plasma glucose concentration [4] was measured in the diabetic patients on capillary blood from the ear three times daily at 7 A.M., 1 P.M. and 5 P.M. The meals were given at 8 A.M., 12 A.M. and 6 P.M.

Other laboratory investigations included determination of haemoglobin concentration and serum creatinine concentration. The urine was examined for the presence of ketone bodies and the glucose concentration was estimated.

\section{Patients}

Six control subjects were studied, five men and one woman, with ages ranging from 23 to 32 years and averaging 26 years.

Six diabetic patients were studied, four men and two women, with ages ranging from 15 to 30 years and averaging 21 years.
All the diabetic patients had classical juvenile diabetes, and none had been treated with insulin before the initial experiments.

Approximately one week after admission to hospital treatment including diet and insulin was started. The patients were treated with rapid and long-acting insulin in various combinations administrated at least twice daily. Considerable effort was made to keep the blood sugar as close to normal levels as possible (see Table 1 for illustration).

Table 1. The relationship between blood glucose concentration measured three times a day and vibratory perception threshold measured with the classical technique on the right leg (case FL), and expressed as the 30 -min value (volt) or the time of disappearance of perception (min). The threshold values obtained with the modified technique were 20 volt (7.7) and 26 volt (29.7)

Date Blood glucose concentration ( $\mathrm{mg} \%$ ) Threshold (30 7 A. M. $\quad 1$ P. M. 5 P. M. $\underset{\text { technique) }}{\text { min) (classical }}$

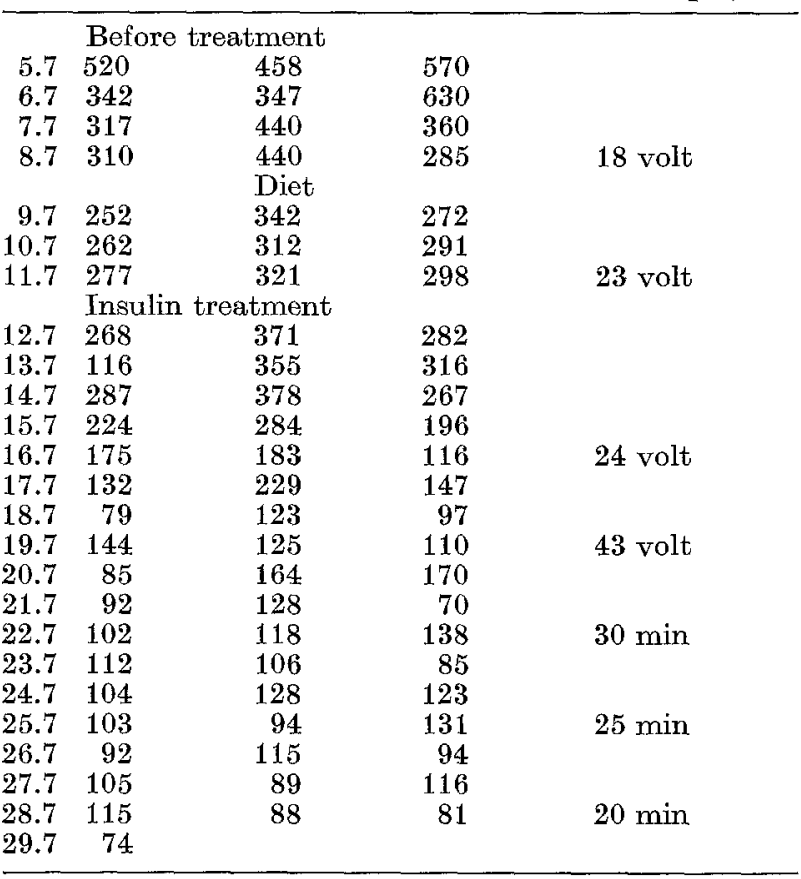

Results

Values of the vibratory perception threshold obtained during intact circulation were identical in the control subjects and in the diabetic subjects, and averaged 8 volt and 7 volt, respectively.

\section{Measurements with the classical technique}

The pattern of the vibratory perception threshold measured during ischaemia produced by arterial occlusion at the level of the knee, is shown at the left side of Figs. 1, 2 and 3.

In the non-diabetics threshold values increased slightly during the first $10-15 \mathrm{~min}$ of ischaemia. Thereafter threshold values increased rapidly. No 
vibrations could be felt by the subjects after $25 \mathrm{~min}$ (Fig. 1).

In the untreated diabetic patients the threshold
Table 1 shows the value for the vibratory perception threshold obtained on the right leg in case FL using the classical technique before and during insulin
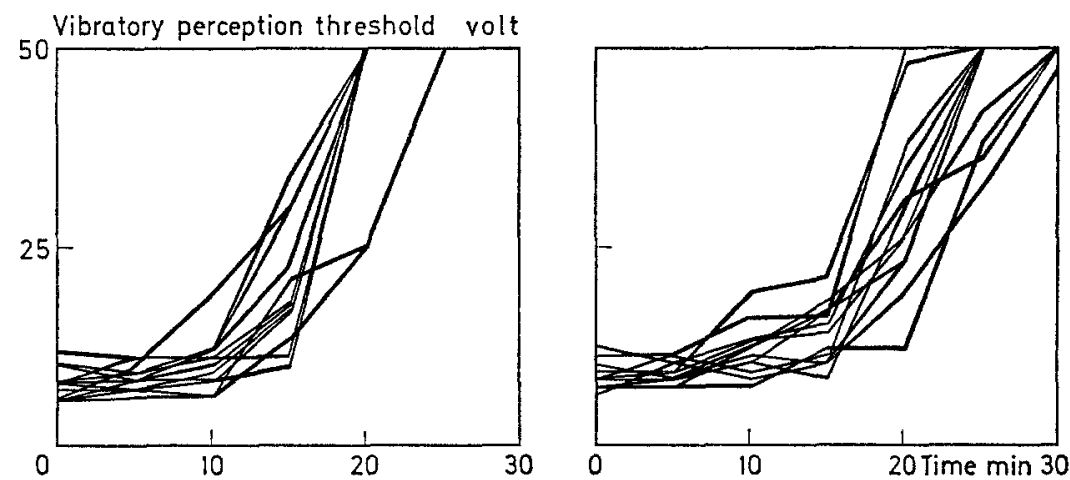

Fig. 1. Vibratory perception threshold (volt) measured in the big toe before and at $5 \mathrm{~min}$ intervals during $30 \mathrm{~min}$ of ischaemia in control subjects. Left part: classical (knee) technique. Right part: modified (ankle) technique
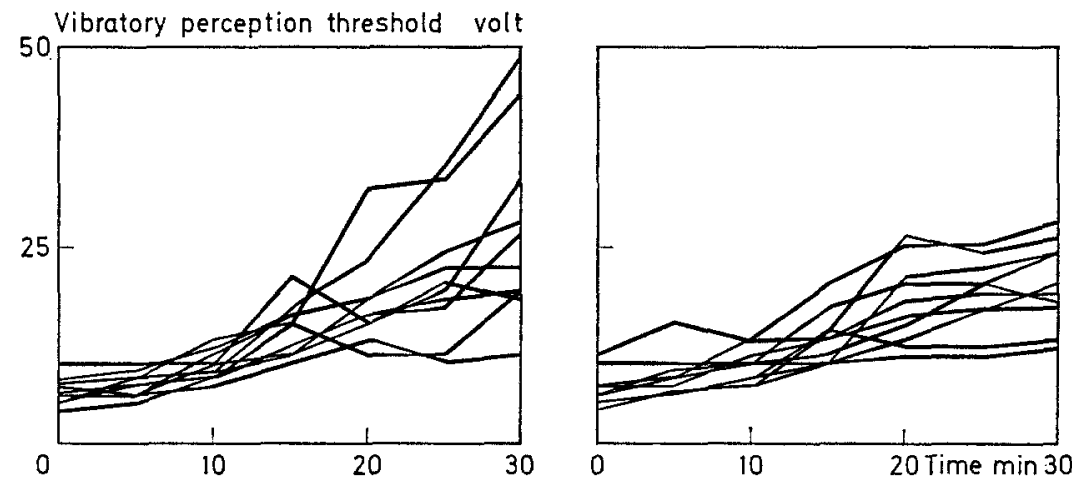

Fig. 2. Vibratory perception threshold (volt) measured in the big toe before and at $5 \mathrm{~min}$ intervals during $30 \mathrm{~min}$ of ischaemia in untreated juvenile diabetics. Left part: classical (knee) technique. Right part: modified (ankle) technique
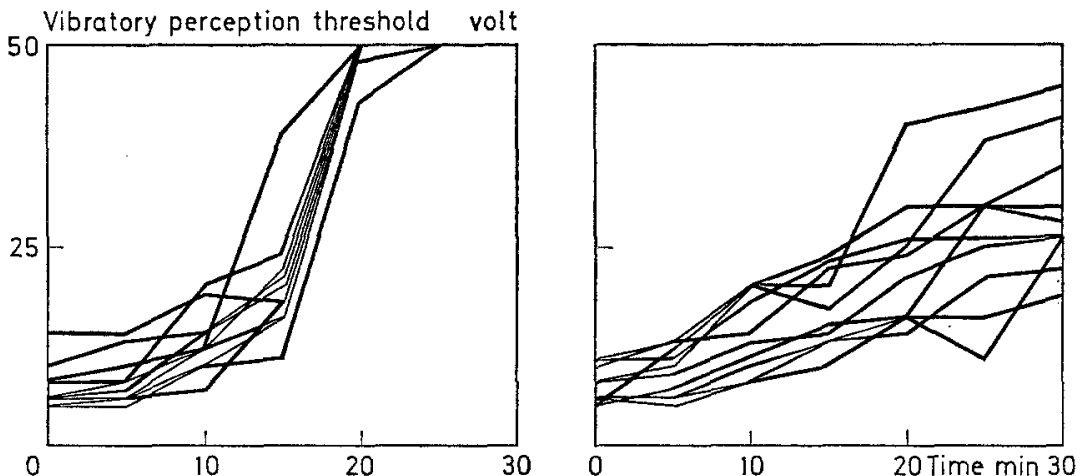

Fig. 3. Vibratory perception threshold (volt) measured in the big toe before and at $5 \mathrm{~min}$ intervals during $30 \mathrm{~min}$ of ischaemia in juvenile diabetics during insulin treatment. Left part: classical (knee) technique. Right part: modified (ankle) technique

values remained low or increased only slightly during the whole period of ischaemia (Fig. 2).

These results are in accordance with those obtained by Steiness [11] in a study of a much larger group of patients. treatment. Threshold values have been expressed as 30-min values (volt) or time of disappearance of perception (min). Blood glucose concentration measured three times daily is also given. As can be seen from the table, the blood glucose values were only slightly out- 
side the normal range during the greater part of the period of insulin therapy.

Threshold values increased slowly after normalization of the blood glucose concentration and the response finally became normal.

It appears from Fig. 3 (left side) that the threshold response during ischaemia in the six diabetics became completely normal during the period of insulin therapy and there were no differences at any point of time between these results and those obtained in the controls.

Table 2. Number of days of insulin treatment required to normalize vibratory perception threshold as measured by the classical technique

\begin{tabular}{llll}
\hline Case & Age & Sex & Insulin treatment (days) \\
\hline MN & $\mathbf{2 1}$ & F & 12 \\
HF & 15 & F & 23 \\
KS & 18 & M & 31 \\
ES & $\mathbf{3 0}$ & M & 12 \\
FL & 23 & M & 17 \\
FH & $\mathbf{2 1}$ & M & 12 \\
\hline
\end{tabular}

Table 2 shows the length of insulin therapy required to normalize the vibratory perception threshold pattern during ischaemia. The range obtained was 12 to 31 days (average 18 days).

\section{Measurements with the modified technique}

The right side of Figs. 1, 2 and 3 illustrates the threshold values obtained when the arterial occlusion cuff was placed at the level of the ankle.

The pattern of the vibratory perception threshold obtained during ischaemia using the modified technique in the controls, has the same general appearance as that obtained using the classical technique. However, the threshold values were lower after 15 and $20 \mathrm{~min}$ and vibratory sensation disappeared approximately 5 min later (Fig. 1).

The results obtained in diabetics before treatment are in accordance with the results obtained in the same patients employing the classical technique, i.e. sensory transmission is preserved much longer during anoxia than in the controls (Fig. 2).

The right side of Fig. 3 shows the threshold values obtained in the big toe in the diabetics when the cuff was placed around the ankle on the day of insulin treatment, when complete normalization had been achieved when the proximal arterial cuff was used. Values obtained when the cuff was placed in this more distal position on the extremity are still very abnormal, although a slight normalization has possibly occured.

\section{Discussion}

The present study confirms previous findings to the effect that nerve transmission is abnormal in young diabetics, even those with recently diagnosed diabetes. The most characteristic disturbance is a peculiar resist- ance to anoxia, which affects afferent as well as efferent nerve conduction. The most simple way to demonstrate the presence of this abnormal phenomenon is to measure the vibratory perception threshold in the big toe during ischaemia. Untreated as well as moderately well-treated diabetics, perceive vibrations readily after at least $30 \mathrm{~min}$ of ischaemia, at a time when no vibrations at all are felt by normal subjects.

Steiness [12] showed that it was possible to normalize this abnormality in diabetics by careful treatment with insulin. This was also found by Gregersen [5]. There is, however, no information about the time required to obtain a completely normal response during insulin therapy in young patients with recently diagnosed diabetes.

In the present study normalization took place in these patients after 12 to 31 days (mean 18 days) of insulin therapy.

The pathophysiological basis for this reversible abnormality of nervous function is not known.

It has been proposed elsewhere, in part due to the finding of a similar phenomenon in uraemic patients, that the mechanism involved is a widespread, although not necessarily extensive, internodal or paranodal demyelination of the nerves. During ischaemia the resting membrane and action potential of the nerve decrease to a point where conduction is no longer possible. The abnormally prolonged preservation of sensory and motor conduction observed in the diabetics and uraemics during ischaemia, is thought to be due to a facilitation of conduction produced by focal areas of demyelination, which reduce the saltatory distances by acting as new points of depolarization [2].

Normalization of the response is therefore believed to be due to remyelination.

The theory implies that a normal response during ischaemia is obtained when remyelination of a very small part of the nerve fibre has occured, since this area will stop the saltatory impulse at the same time as would be the case if the whole nerve fibre was fully remyelinated.

The results obtained in the present study show unequirocally that a normal response can be obtained with the classical technique, even though the section of nerve distal to the ankle still demonstrates a clearly abnormal response. The observations presented here, are therefore in accordance with the morphological explanation offered above. Other explanations of the results might be considered. There can be no doubt, however, that a number of observations are easily explained or are in support of the opinion that the ischaemic abnormalities are caused by a defective myelin sheath.

This theory explains not only the observations presented here. It also explains in a simple way the presence of the same abnormalities in patients with uraemia [2] and pernicious anaemia (unpublished observations), as demyelination of the nerves is a prominent morphological feature in these two conditions. 
The morphological explanation is in accordance with the fact that young diabetics with a recently diagnosed and untreated diabetes also show a reduced motor conduction velocity which can, at least partially, be normalized during treatment with insulin [6]. Seneviratne and Peiris [10] have recently demonstrated. that nerve conduction in isolated nerves from alloxandiabetic rats is preserved better during anoxia compared with non-diabetic rats. These authors studied the morphological picture of the nerves from the alloxan-diabetic rats and found conspicuous widening of the nodal gap and fragmentation of the myelin in the internodal region. Furthermore, Eliason [3] have recently shown that the resistance of the internodal segment is considerably reduced in nerve preparations from alloxan-diabetic rats.

The present study demonstrates that normalization of nervous function during treatment with insulin is not fully achieved everywhere along the nerve fibre at the same time. The distal parts of the nerves are more severely affected. The findings cannot be explained by the different length of the nerve fibres included in the two measurements, i.e. that the longer segment will have a greater chance of containing an entirely normalized part, as originally proposed [2]. The distance from the toe to the ankle is approximately one third of the distance from the toe to the knee, and consequently a normal response should have been obtained at the same time approximately every third time. We have invariably found that the vibratory perception threshold response to ischaemia is abnormal when the cuff is placed in the distal position, at the time when a normal response is elicited with the cuff placed at more proximal levels. This has been our experience not only in the diabetic patients reported here, but also in a few patients with pernicious anaemia studied during treatment with vitamine $\mathrm{B}_{12}$ (unpublished observations), as well as in a few diabetics where the threshold values were measured in the finger and the cuff placed above the antecubital space and at the level of the wrist, respectively.

The reason for this is not clear. Perhaps repair occurs at a greater rate in the proximal parts of the nerves. Animal experiments [8] seem to indicate that the ability to synthesize myelin lipids is greater in the proximal parts of the nerves. Another explanation could be that repair is inhibited in the foot because of repeated mechanical pressure on the nerves [7]. It is unlikely, however, that this can be the sole explanation, since we have obtained results identical to those presented here when the pattern of the vibratory perception threshold was measured in the finger, and the arterial occlusion cuff placed either above the antecubital space or at the level of the wrist.

\section{References}

1. Castaigne, P., Cathala, H.-P., Dry, J., Mastropaolo, C.: Les réponses des nerfs et des muscles à des stimulations électriques au cours d' une épreuve de garrot ischaemique chez l'hommo normal et chez l'homme diabétique. Rev. nourol. 115, 61-66 (1966).

2. Christensen, N. Juel, Ørskov, H.: Vibratory perception in uraemic patients and in subjects with mild carbohydrate intolerance. J. Neurol. Neurosurg. Psychiat. 32, 519-524 (1970).

3. Eliasson, S.G.: Propərties of isolated nerve fibers from alloxanized rats. J. Neurol. Neurosurg. Psychiat. 32, 525-529 (1969).

4. Feteris, W.A.: A serum glucose method without protein precipitation. Amer. J. med. Technol. 31, 17-21 (1965).

5. Gregersen, G.: A study of the peripheral nerves in diabetic subjects during ischaemia. J. Neurol. Neurosurg. Psychiat. 31, 175-181 (1968).

6. - Variations in motor conduction velocity produced by acute changes of the metabolic state in diabetic patients. Diabetologia 4, 273-277 (1968).

7. Hopkins, A.P., Morgan-Hughes, J.A.: The effect of local pressure in diphtheritic neuropathy. J. Physiol. (Lond.) 189, 81P - 82P (1967).

8. Manjo, G., Karnovsky, M. L. : A biochemical and morphologic study of myelination and demyelination. J. exp. Med. 107, $475-496$ (1958).

9. Seneviratne, K.N., Peiris, O.A.: The effect of ischaemia on the excitability of sensory nerves in diabetes mellitus. J. Neurol. Neurosurg. Psychiat. 31, $348-353$ (1968).

10. - - The effect of hypoxia on the excitability of the isolated peripheral nerves of alloxan-diabetic rats. J. Neurol. Neurosurg. Psychiat. 32, $462-469$ (1969).

11. Steiness, I.: Vibratory perception in diabetics during arrested blood flow to the limb. Acta med. scand. 163, $195-205(1959)$.

12. - Influence of diabetic status on vibratory perception during ischaemia. Acta med. scand. 170, 319-338 (1961).

13. - Diabetic neuropathy. Vibration sense and abnormal tendon reflexes in diabetics. Thesis. Acta med. scand. Suppl. 394 (1963).

N.J. Christensen, M.D.

2nd Clinic of Internal Medicine

Kommunehospitalet

Arhus University School of Medicine

Århus, Denmark 